\author{
R.Sh. Sabirova ${ }^{1}$, M.M. Umurkulova ${ }^{1, *}$, Ben C.H. Kuo ${ }^{2}$ \\ ${ }^{1}$ Karagandy University of the name of academician E.A. Buketov, Kazakhstan; \\ ${ }^{2}$ University of Windsor, Ontario, Canada \\ (E-mail: madinaumurkulova@mail.ru)
}

\title{
Academic stress at different yearsof study
}

\begin{abstract}
The article describes the results of a study of academic stress in 119 psychology students of the Faculty of Philosophy and Psychology of Karaganda State University. The author substantiates the relevance of the stress problem arising in the process of educational activity. The necessity of enriching the diagnostic arsenal of psychologists and teachers with new methods for academic stress research is shown. An empirical study identified objective and subjective sources, mental and somatic manifestations of stress. The dynamics of the course of academic stress at different stages of study at the university is revealed. The results obtained by the authors of the article demonstrate the greatest severity of all parameters of physical and psychological distress at first and fourth years of study. The non-adaptive nature of coping strategies used by students of different grades to stop the negative psycho-emotional experiences associated with stress in educational activities is disclosed. The necessity of psychological and pedagogical support of students in situation of academic stress is shown. The general characteristic of the support program developing personality resources of the students is given, taking into account new methodological approaches to skills and learning strategies.
\end{abstract}

Keywords: academic stress, stress dynamics, coping behavior, coping, students' mental health, stress diagnostics, educational activities, support, training skills, resource approach.

\section{Introduction}

Recently, more and more social and economic changes are affecting all spheres of public life, including the sphere of education. The state sends a significant amount of material resources to the higher education system. It is logical that society places ever greater demands on the learning of a comprehensively trained specialist. University graduate should possess not only professionally significant skills, knowledge and competencies that determine his high efficiency as a future specialist. Along with this, a professional should be endowed with special abilities, referred to in the foreign scientific literature as «soft skills» [1]. The essence of such skills is the ability to reasonably set goals and achieve them, the ability to properly organize time, build constructive social contacts and much more. A special place among such skills is occupied by the ability to withstand emerging life and professional difficulties, to successfully overcome various external and internal obstacles without harming one's physical and mental health. In this regard, the question of the formation of stress-overcoming behavior (coping behavior in foreign sources) is especially acute $[2,3]$.

Of course, stress has become a constant concomitant of life for every person, regardless of gender, age and occupation. Also, there is no doubt that the student age is one of the most stressful periods in the life of every young person studying in a higher educational institution. The whole spectrum of negative physical and emotional states associated with the educational process is described in the psychological and pedagogical literature by the term «academic stress» $[4,5]$.

Numerous studies have shown that academic stress is a widespread phenomenon among students. Providing a non-adaptive effect on activity and behavior, academic stress negatively affects the success of a student's adaptation to the educational environment, reduces educational motivation, and worsens academic performance [6, 7].

There are a number of factors that trigger the occurrence and intensification of academic stress. These include changes in the familiar environment and lifestyle, inefficient self-organization, a large amount of academic workload, poor self-control skills, the need to adapt to a new social environment, etc. A survey conducted by us among students of various faculties of the Karaganda State University showed that the level of stress associated with studies is quite pronounced [8;160]. In such situation, the question of overcoming the contradiction between the need for an in-depth study of the picture of academic stress among students and the lack of a focused, scientifically sound and practically verified approach to providing psychological

\footnotetext{
${ }^{*}$ Corresponding author's e-mail: madinaumurkulova@mail.ru
} 
and pedagogical support to students in situations of stress becomes obvious. An attempt to find ways to resolve this contradiction determines the purpose of our study.

This article describes one of the stages of examination the academic stress of higher educational institutions of Karaganda city, carried out as part of the dissertation. The results of research the dynamics of stress at different stages of study at a university will be described below. The authors conducted a comparative analysis of the causes and signs of stress experienced by students of various courses of the Faculty of Philosophy and Psychology. Our goal was to find out which factors are stressful for students, and how exactly stress manifests in first-year students, second and third year students, as well as university graduates. In addition, it will be advisable to find out what ways of stress management are used by students to identify nonadaptive behavioral strategies and subsequently make them the object of psychological and pedagogical correction.

\section{Methods}

It should be noted that in domestic psychological and pedagogical arsenal there is a significant lack of diagnostic tools that would allow to consider carefully all the manifestations of academic stress and all ways of coping with it. Therefore, we were faced with the issue of adaptation for a Russian-language sample in Kazakhstan of a foreign methodology designed for such purposes.

We opted for The Student Well-Being Process Questionnaire (A. Smyth, UK) [9]. This questionnaire is quite widely and successfully used in the activities of the psychological services of universities and colleges in the UK. Our choice was justified by the fact that this tool allows to identify not only what factors and with what intensity affect the occurrence of stress, but also to determine how successfully a student copes with difficulties and obstacles that arise during his studies, what kind of coping strategies he uses for this. With the permission of the author of the method, we carried out cross-cultural adaptation of the questionnaire and used it in our study.

The adapted questionnaire has 8 scales:

- positive well-being- includes questions about mood, general satisfaction with life, the quality of relationship with others; haustion;

- negative well-being - an assessment of anxiety, depressive manifestations, physical and mental ex-

- Student stressors - issues related to student-specific problems: separation from family, change of lifestyle and environment, lack of time;

- social resource - questions about the availability of material, emotional and spiritual social support;

- positive coping - reveals effective problem-oriented strategies for coping with stress;

- negative copying - determines the presence of unsuccessful copying strategies of self-accusation, avoidance, etc.;

- personal resource - an analysis of the personality stress-overcoming resource;

- academic workload - the identification of external objective conditions associated with the study load, stressfulness of study, etc.

The next method that we used in accordance with our goal was the «Test for educational stress» developed by Yu.V. Shcherbatykh [10].

At the moment, this questionnaire is gaining popularity in Russian studies, but it is relatively rarely used in the Kazakhstani scientific environment. The questionnaire, for all its brevity, is quite informative, and suggests answers to a wide range of questions. In particular, the questionnaire identifies:

- the contribution of separate factors to the overall phenomenon of stress;

- the dynamics of educational stress;

- the level of pre-examination excitement;

- ways to relieve pre-examination anxiety;

- physical and mental signs of stress.

The total number of psychology students participating in our study was 119 . The study involved 30 first-year students, 41 second-year students, 32 third-year students and 16 fourth-year students.

\section{Results}

The findings provide an opportunity to judge what is caused stress, what expressed one is and how students overcome stress associated with learning factors. 
The table below reflects the average group results obtained with the student well-being questionnaire from psychology students of different grades. The data demonstrate a wide range of severity of academic stress, as well as a wide range of coping strategies used by students. In addition, there is a change in the nature of stress from the first year to the final year of study, which allows us to identify some patterns in the dynamics of educational stress.

It was found that the level of general mental and somatic well-being of students varies from year to year. First-year students have a pronounced level of negative symptoms in the form of anxiety, emotional burnout, physical fatigue and mental fatigue (7.4 points out of 10 maximum). The symptoms of negative well-being decrease in the 2 nd year (4.1 points) and reach minimum in the 3 rd year (1.4 points). On the 4 th year we observe a repeated increase in the severity of negative psychical and physiological conditions, which is seen by high rates - 7.9 points. The data are presented in table 1 .

$\mathrm{Tab}$ a 1

Group average indicators of student well-being questionnaire, points

\begin{tabular}{|l|c|c|c|c|}
\hline \multicolumn{1}{|c|}{\begin{tabular}{c} 
Academic Stress Parameters and \\
\multicolumn{1}{c|}{ coping resources }
\end{tabular}} & First & Second & Third & Foutrh \\
\cline { 2 - 5 } & 3,6 & 5,3 & 8,1 & 4,1 \\
\hline Positive well-being & 7,4 & 4,1 & 1,4 & 7,9 \\
\hline Negative well-being & 8,1 & 6 & 3,4 & 9 \\
\hline Student stressors & 2,8 & 4,8 & 7,5 & 7 \\
\hline Social resource & 3 & 4 & 5,3 & 4 \\
\hline Positive coping & 8 & 8,2 & 7,9 & 7,1 \\
\hline Negative coping & 1,6 & 6 & 7,1 & 4 \\
\hline Personal resource & 8,2 & 6,2 & 6,5 & 8,9 \\
\hline Academic workload & & & & \\
\hline
\end{tabular}

The number of stressful factors is high in the 1 st year ( 8.1 points) and in the 4 th year (9 points). For second-year and third-year students, indicators on this scale are in the range of moderate values.

It was found that the social resource is weakly expressed at the beginning of learning, at the 1st and $2 \mathrm{nd}$ grades (2.8 and 4.8 points, respectively). The growth trend of the social resource is noted at the 3rd year ( 7.5 points) and the 4 th year ( 7 points).

As for coping strategies, it can be noted that unfortunately students use non-adaptive coping methods. This is evidenced by the fact that indicators for negative coping are much higher than indicators describing positive coping.

The analysis of the personal resource showed that in freshmen it is not actually formed (1.6 points). However, by the second and the third year personal resource is accumulated, which is reflected in the growth of data to 6 and 7.1 points at the 2nd and 3rd courses, respectively. Unexpectedly, by the end of their studies, the students' personal potential is again reduced to 4 points.

Finally, students unequally assess the academic workload. Most freshmen consider the workload very high ( 8.2 points according to their feelings). Then there is a gradual decrease in the results at the 2nd (6.2 points) and 3-year study (6.5 points). Graduates note an increase in the academic workload to 8.9 points.

General patterns confirm the data obtained by Sherbatykh questionnaire. Students of all courses, with the exception of the 3rd year, revealed that the most stressful situations for them is the excessive class workload - 7.9 points for first-year students, 7.3 points for 2 nd year students, 7.8 points for graduates.

In addition to a high academic load, strict teachers and the inability to properly organize the regimen of the day are significant stressful factors for students of 1 st year.

The students of first year note incomprehensible and boring textbooks and a reluctance to study as a source of stress. For third-year students stress is mainly associated with an excessive serious attitude to study, irregular eating habits and a fear of the future.

Graduates call the main causes of stress, in addition to a large academic load, fear of the future and problems in their personal lives.

Graphically, the results are presented in the diagram below, which shows the three main reasons that make the greatest contribution to the occurrence of stress and the appearance of subjective discomfort among students of different years of study (Figure 1). 


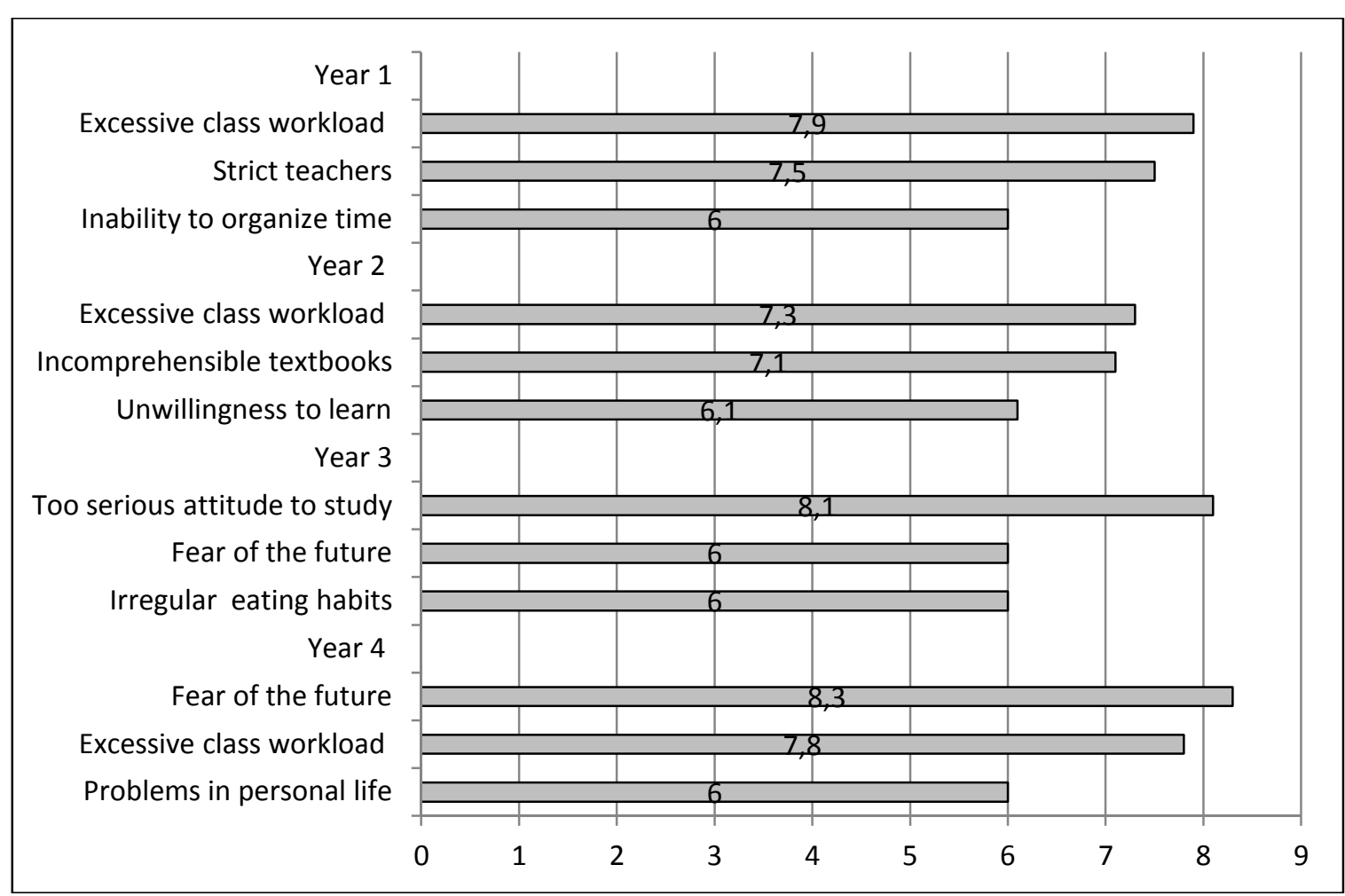

Figure 1. Sources of academic stress, points

The second diagram demonstrates the manifestations of stress associated with learning (Figure 2). The diagram shows the 3 most striking signs that students of various courses noted.

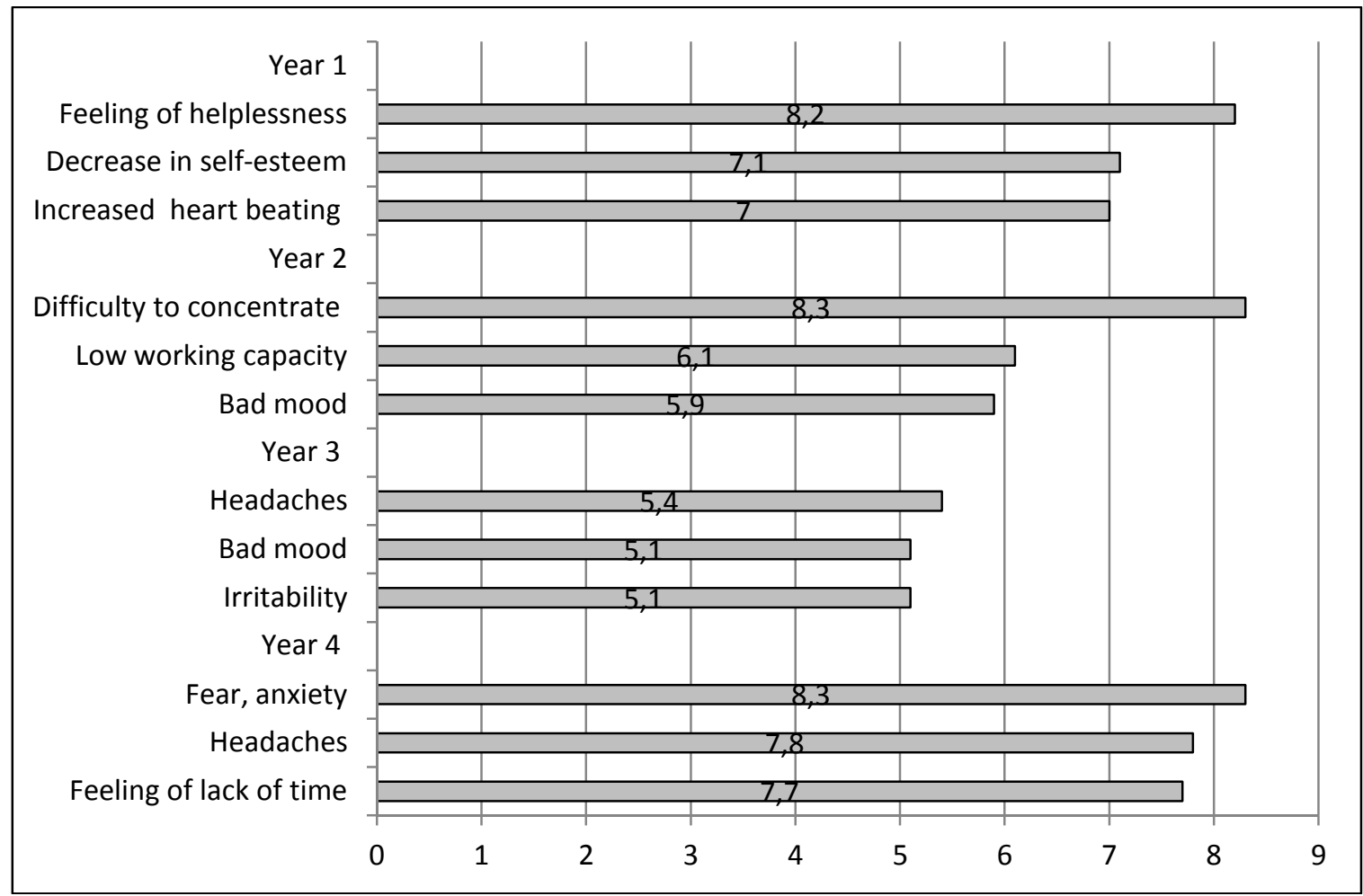

Figure 2. Manifestations of academic stress, points. 


\section{Discussion}

The symptomatic indicators of exam stress are clearly represented in all groups of subjects, and data reach significant levels. First-year students note a feeling of helplessness, inability to cope with problems; decreased self-esteem and self-confidence; unpleasant sensations from the cardiovascular system.

Second-year students say that stress manifests in the form of a decrease in concentration of attention and increased distractibility, poor performance and a bad mood. The third year students complain of recurring headaches; irritability and bad mood. Final year students added to this list a sense of fear and anxiety; headaches; feeling of constant rush and lack of time.

When asked how stress levels have changed in recent months, freshmen responded that stress has increased significantly; sophomores note a decrease in stress levels. According to the feelings of third-year students, the level of stress has not changed. Graduates note a significant increase in stress.

Analysis of the pre-examination excitement showed that students of all grades, except the 3rd year, rate its severity as reasonably high. The students of 1 st year assigned 8.5 out of 10 points to the pre-examination excitement, the second year undergraduate students -7 points, graduate students even more 9.1 out of 10 points. This indicates a pronounced degree of emotional stress, increased excitement and feelings of uncertainty immediately before the exam. Undoubtedly, it negatively affects the success of passing the test.

Comparing the findings, we can conclude that the excessive academic workload is the main factor triggering academic stress in the vast majority of students, regardless of the year of study. The results obtained for this parameter significantly exceed normal values, which indicate a special place that the class workload occupies in the occurrence of a stressful state.

The general trend in the dynamics of the development of academic stress is that its highest level is observed in the first and last years of study. The number of stressors is also subject to this trend, decreasing by the second year and increasing by the final year of study. On the contrary, subjective psychological wellbeing is changing in the opposite direction - in the first and fourth year its lowest indicators are revealed.

In other words, first and final study years are the most stressful for students. And this is not surprising, since both the first and the final courses have their own specific features. In the first year, this is due to the need for quick and effective adaptation to the new social environment, the requirements of the university, and a significant increase in the number of educational tasks performed.

From this point of view graduates also belong to the risk group. Firstly, this is due to a sharp increase in the workload in connection with passing state exams and the defense of diploma. Secondly, the graduation year is period of summing up certain results, and at the same time, the beginning of a new phase of life associated with upcoming employment, continuing studies in a magistracy, getting a second education, and for some students - with marriage. This can explain the graduates' certain pessimism and fear regarding their own future.

The second and third courses are in a better position. Final exams have not yet acquired their relevance, students managed to adapt to the rhythm of student life, orientated themselves in the requirements of teachers, built new social connections. However, a certain decrease in the level of educational motivation refers to this period, when students are reluctant to study. They are faced with disappointment in their chosen specialty, and the subjects studied seem boring and useless. This transient state lasts until the end of the second course.

In addition to objective reasons determining the formation and dynamics of stress associated with learning factors, there are intrapersonal conditions that determine the severity of stress in students of various years of study. It is well known that one and the same adverse circumstance can cause the most diverse, often opposite reactions in different individuals. Important is not only the nature of the event itself, but also its perception by person, assessment and choice of ways out of a difficult situation. This statement is confirmed by the results of the study.

Indeed, the assessment of academic stress and students' resistance to stress are directly related to the adaptability of the used forms of coping behavior, as well as personal resources that determine the success of coping with stress. Students of all grades have a poorly developed social resource for coping. They are not sufficiently capable of seeking and accepting the support of others. The accumulation of this type of resource begins only by the period of graduation, by the 4th year of study. The level of self-esteem and student selfefficacy is also underdeveloped.

As for coping strategies, its adaptive forms are found in a small part of students. Most of the subjects use ineffective ways out of stressful situations, such as avoiding, wishful thinking and self-blaming. Accord- 
ing to researchers, such strategies lead to the consolidation of stressful symptoms, to addictive behavior, to the inability of a comprehensive analysis and successful solution of the problem.

\section{Conclusions}

Summarizing the results of the study, it can be argued that academic stress is a serious obstacle to maintaining the mental health of students. The findings demonstrate pronounced symptoms of exam stress at all stages of learning. This leads not only to a deterioration in the quality of life of the student, but also to a decrease in his academic performance, social des adaptation, and requires serious targeted psychological and pedagogical intervention $[11,12]$.

One of the most important ways of such assistance is the program for psychological and pedagogical support of a student in a situation of academic stress developed by the author of the article. Unlike other programs of this kind, this program is not limited only to the correction of the emotional state of the person.

One of the parts of the proposed program focuses on the removal of acute emotional states, for example, on the relief of pre-examination excitement through the formation of self-regulation skills. However recognizing the importance of affective experiences, we note that negative emotions act only as indicators, manifestations of stress. The program we offer has an etiological focus, in other words, it is aimed at research and eliminating the causes of stress.

Since the change in the academic workload of educational programs developed by the university is not possible and even advisable, the support program focuses on increasing the individual's resources. We proceed from the assumption that if external objective conditions, for example, high intellectual or information load, are not amenable to change, then only strengthening the internal potential can help overcome various negative environmental factors $[13,14]$. Therefore, the support program serves the formation and strengthening of the communicative, emotional, social and other resources of the individual.

Separate parts of the program are aimed at developing cognitive abilities, in accordance with innovative approaches to the educational process. An example of this would be teaching skills in accordance with Kolb's styles, Danlowski learning strategies, and cognitive loading theory. These theories are widely used abroad and have already proven their effectiveness [15].

In addition, the objectives of the program are the formation of correction of educational motivation, critical thinking, goal-setting skills, time management, the formation of soft skills, as well as the facilitation of successful problem solving and decision-making skills. Such work will lead to increased student selfefficacy, strengthen positive educational motivation, and ultimately increase his academic achievement.

Thus, an experimental investigation proves that academic stress is a complex multi component phenomenon that has its own dynamics and specific features. Elimination, or at least mitigation of the stress associated with learning is an urgent task facing not only psychologists and teachers, but also all subjects of the educational space of higher education.

\section{References}

1 Lippman L.H. Workforce Connections: Key «soft skills» that foster youth workforce success: toward a consensus across fields / L.H. Lippman, R. Ryberg, R. Carney, K.A. Moore. - Washington, DC: Child Trends, 2015. - 56 p.

2 Lazarus R. Stress, appraisal and coping / S. Folkman, R. Lazarus. — New York, Springer Publishing Company, 1984. — 460 p.

3 Regehr C.A. Interventions to reduce stress in university students: a review and meta-analysis / C. Regehr, D. Glancy, A. Pitts // European Psychiatry. — 2013. — № 148. — P.1-11. DOI:10.1016/j.jad.2012.11.026.

4 Agarwal A. Impact of academic stress upon academic achievement and mental health of the adolescents / A. Agarwal // International journal of management and social sciences. — 2011. — № 1(1). - P. 79-87.

5 Mechanic D. Students under stress: a study in the social psychology of adaptation / D. Mechanic. — Madison: University of Wisconsin Press, 1978. — 231 p.

6 Артюхова Т.Ю. Психологическое здоровье участников образовательного процесса как основа психологической безопасности / Т.Ю. Артюхова // Человеческий фактор: проблемы психологии и эргономики. — 2006. — № 2. - С. 26-29.

7 Баева И.А. Психологическая безопасность в образовании: моногр. / И.А. Баева. — СПб.: Питер, 2002. — 271 с.

8 Умуркулова М.М. Специфические особенности академического стресса студентов и их учет в учебном процессе /М.М. Умуркулова, Р.Ш. Сабирова // КазНПУ им.Абая. — Педагогические науки. — 2019. — № 4 (64). — С. 158-164.

9 Smith A.P. The Student Well-Being Process Questionnaire (Student WPQ) / G.M. Williams, H. Pendlebury, K. Thomas, A.P. Smith // Psychology. — 2017. — № 8. - P. 1748-1761.DOI: 10.4236/psych.2017.811115.

10 Щербатых Ю.В. Психология стресса и методы коррекции / Ю.В. Щербатых. — СПб.: Питер, 2006. - 256 с.

11 Крюкова Т.Л. Психология совладающего поведения / Т.Л. Крюкова. — Кострома: Авантитул, 2004. - 343 с. 
12 Щербатых Ю.В. Экзаменационный стресс / Ю.В. Щербатых. — Воронеж, 2006. — 120 с.

13 Меньшикова И.Н. Решение проблемы адаптации студентов в рамках психологической службы вуза / И.Н. Меньшикова, О.В. Соловьева // Вестн. СтавГУ. — 2007. — № 52. - С. 71-75.

14 Сергеева О.М. Изменение структуры учебной мотивации в условиях экзаменационного стресса / О.М. Сергеева, С.Б. Парин // Вестн. ННГУ. — Сер. Социальные науки. — 2005. — № 1(4). — С. 80-90.

15 Dunlosky J. Improving students' learning with effective learning techniques promising directions from cognitive and educational psychology / J. Dunlosky, K.A. Rawson, E.J. Marsh, M.J. Nathan, D.T. Willingham // Psychological Science in the Public Interest. - 2013. - № 14 (1). - P. 4-58.

\title{
Р.Ш. Сабирова, М.М. Умуркулова, Бен Ч.С. Куо Әр түрлі оқу жылдарындағы академиялық стресс
}

\begin{abstract}
Мақалада Академик Е.А. Бөкетов атындағы Қарағанды университеті философия және психология факультетінің әр түрлі курстарында оқитын 119 психолог-студенттердің академиялық стресін зерттеу нәтижелері сипатталған. Авторлар оқу әрекеті процесінде туындайтын стресс мәселесінің өзектілігін негіздейді. Академиялық стресс пен стресті жеңетін жүріс-тұрыстың (копинг әрекетінің) психологиялық мәні және оқу процесіне жасайтын ықпалы бейнеленген. Психологтар мен оқытушылардың диагностикалық арсеналын академиялық стресті зерттеудің жаңа әдістерімен байыту қажеттілігі көрсетілген. Мақала авторлары өздері аударған және бейімдеген, бұрын Қазақстанда қолданылмаған студенттердің субъективті саулығын зерттеуге арналған ағылшын тіліндегі сауалнаманы ұсынған. Эмпирикалық зерттеу стрестің объективті және субъективті көздерін, психикалық және соматикалық көріністерін, оның теріс салдарын анықтайды. Университетте оқудың әр түрлі кезеңдеріндегі пайда болатын академиялық стрестің даму динамикасы анықталды. Мақала авторларының анықтаған нәтижелері бірінші және төртінші курстарда оқитын студенттерде физикалық және психикалық күйзелістің барлық параметрлерінің едәуір ауыр болатынын дәлелдейді. Әр түрлі курстарда оқитын психолог-студенттердің оку іс-әрекетіндегі стрестен туындаған теріс психоэмоционалды күйлерін жеңу үшін қолданатын жүріс-тұрыстарының қолайсыз, дезадаптивты сипаты анықталды. Сонымен қатар, мақалада академиялық стресс жағдайындағы студенттерді психологиялық-педагогикалық қолдаудың қажеттілігі, студенттердің психикалық денсаулығын жақсарту және оқу іс-әрекетінің тиімділігін арттыру үшін пайдалынатын қолдаудың маңыздылығы көрсетілген. Оку дағдылары мен оқыту стратегиясының жаңа әдіснамалық тәсілдерін қолданатын, оқушының эмоционалды, танымдық, тұлғалық, әлеуметтік ресурстарымен жұмыс жасайтын қолдау бағдарламасының жалпы сипаттамасы берілген.
\end{abstract}

Кілт сөздер: академиялық стресс, стрестің динамикасы, копинг әрекеті, студенттердің психикалық денсаулығы, стресс диагностикасы, білім беру қызметі, қолдау, оқыту стратегиялары, ресурстық көзқарас.

\section{Р.Ш. Сабирова, М.М. Умуркулова, Бен Ч.С. Куо}

\section{Академический стресс в разные годы обучения}

В статье описаны результаты исследования академического стресса у 119 студентов-психологов факультета философии и психологии Карагандинского университета им. академика Е.А. Букетова разных лет обучения. Авторами обоснована актуальность проблемы стресса, возникающего в процессе учебной деятельности. Раскрыта сущность феномена академического стресса и стресспреодолевающего поведения (копинг-поведения). Показана необходимость обогащения диагностического арсенала психологов и педагогов новыми методами изучения академического стресса. Предложен ранее не применявшийся в Казахстане англоязычный опросник субъективного благополучия студентов, переведенный и адаптированный авторами статьи. В ходе эмпирического исследования были определены объективные и субъективные источники, психические и соматические проявления стрес$\mathrm{ca}$, его негативные последствия. Выявлена динамика протекания академического стресса на разных этапах обучения в вузе. Результаты, полученные авторами статьи, демонстрируют наибольшую выраженность всех параметров физического и психологического неблагополучия на первом и четвертом курсах обучения. Раскрыт неадаптивный характер совладающих стратегий, используемых студентами-психологами разных курсов для купирования негативных психоэмоциональных переживаний, связанных со стрессом в учебной деятельности. Показана необходимость психолого-педагогического сопровождения студентов в ситуации академического стресса, а также выявлено значение сопровождения для улучшения психического здоровья студентов и повышения эффективности учебной деятельности. Дана общая характеристика программы сопровождения, работающей сэмоциональным, когнитивным, личностным, социальным ресурсами личности студента, с учетом новых методологических подходов к навыкам и стратегиям обучения. 
Ключевые слова: академический стресс, динамика стресса, совладающее поведение, копинг, психическое здоровье студентов, диагностика стресса, учебная деятельность, сопровождение, навыки обучения, ресурсный подход.

\section{References}

1 Lippman, L.H., Ryberg, R., Carney, R., \& Moore, K. A. (2015). Workforce Connections: Key «soft skills» that foster youth workforce success: toward a consensus across fields. Washington, DC: Child Trends.

2 Folkman, S., \& Lazarus, R. (1984). Stress, appraisal and coping. New York, NY: Springer.

3 Regehr, C., Glancy D., \& Pitts, D.A. (2013). Interventions to reduce stress in university students: a review and meta-analysis. Journal of Affective Disorders, Vol.148, 1-11. DOI:10.1016/j.jad.2012.11.026.

4 Agarwal, A. (2011). Impact of academic stress upon academic achievement and mental health of the adolescents. International journal of management and social sciences, Vol. 1, 1, 79-87.

5 Mechanic, D. (1978). Students under stress: a study in the social psychology of adaptation. Madison: University of Wisconsin Press.

6 Artyukhova, T.Yu. (2006). Psikholohicheskoe zdorove uchastnikov obrazovatelnoho protsessa kak osnova psikholohicheskoi bezopasnosti [The psychological health of participants in the educational process as the basis of psychological safety]. Chelovecheskii faktor: problemy psikholohii i erhonomiki - The human factor: problems of psychology and ergonomics, 2, 26-29 [in Russian].

7 Bayeva, I.A. (2002). Psikholohicheskaia bezopasnost v obrazovanii: monohrafiia [Psychological safety in education]. Saint Petersburg: Piter [in Russian].

8 Sabirova, R.Sh., \& Umurkulova, M.M. (2019). Spetsificheskie osobennosti akademicheskoho stressa studentov i ikh uchet v uchebnom protsesse [Specific features of students' academic stress and their accounting in the educational process].Vestnik KazNPU imeni Abaia. Seria Pedahohicheskie nauki - Bulletin KazNPU named after Abai. Pedagogical sciences series, 4, 64, 158-164 [in Russian].

9 Williams, G. M., Pendlebury, H., Thomas, K., \&Smith, A.P. (2017).The Student Well-Being Process Questionnaire (Student WPQ).Psychology, Vol. 8, 1748-1761. DOI: 10.4236/psych.2017.811115.

10 Shcherbatykh, Yu.V. (2006). Psikholohiia stressa i metody korrektsii [Psychology of stress and correction methods]. Saint Petersburg: Piter [in Russian].

11 Kryukova, T.L. (2004). Psikholohiia sovladaiushcheho povedeniia [Psychology of coping behavior]. Kostroma: Avantitul [in Russian].

12 Shcherbatykh, Yu.V. (2000). Ekzamenatsionnyi stress [Exam stress].Voronezh [in Russian].

13 Menshikova, I.N., \& Solovyeva, O.V. (2007). Reshenie problemy adaptatsii studentov v ramkakh psikholohicheskoi sluzhby vuza [Solving the problem of students' adaptation in the framework of the psychological service of the university]. Vestnik StavGU - Bulletin of the StavSU, 52,71-75 [in Russian].

14 Sergeyeva, O.M., \& Parin, S.B. (2005). Izmenenie struktury uchebnoi motivatsii v usloviiakh ekzamenatsionnoho stressa [Change in the structure of educational motivation in the conditions of exam stress]. Vestnik NNGU. Seriia Sotsialnye nauki Bulletin of NNSU.Social sciences series, 1, 4, 80-90 [in Russian].

15 Dunlosky, J., Rawson, K.A., Marsh, E.J., Nathan, M.J., \& Willingham D.T. (2013). Improving students' learning with effective learning techniques promising directions from cognitive and educational psychology.Psychological Science in the Public Interest, 14, 1, 4-58. 